\title{
How Local Authorities Implement Decentralization Policy on Education Sector
}

\author{
Ella Wargadinata \\ Faculty of Governmental Management \\ Institut Pertahanan Dalam Negeri \\ Jatinangor, Indonesia \\ Ella@upm.ipdn.ac.id
}

\author{
Mesy Faridah Hendiyani \\ Faculty of Social Science \\ Universitas Bradford \\ Bradford,UK
}

\begin{abstract}
Education is one part of decentralization policy started in $\mathbf{2 0 0 0}$ in Indonesia to raise quality of education services. This study examines some of major premises of its implementation among four cities. The aims of how the local governments managed education sector under their responsibilities, it will consist; financial aspect, local innovation and education services quality This study reveals that there is no significant improvement in primary-high school education before and after decentralization it is conducted by a blended qualitative and quantitative approach and collecting secondary data from various sources were used as a method of enquiry. The implementation of this policy only has minor innovation made by local authorities. Basically, it understands as financial shifting management from central to local level. Moreover, some local authorities made controversy policy through students' contribution for their education cost addition to raise education quality especially in school services.
\end{abstract}

\section{Keywords-Education, Decentralization, Local governments, controversy}

\section{INTRODUCTION}

The tendency of many countries' movement from centralization to decentralization is increasing from year to year. Decentralization probably is the most favorable policy which adopted by countries globally [1]. The new chapter of decentralization in Indonesia began in reformation era in 2000. Decentralization covers administrative, politics and financial aspects. Administrative decentralization policy is giving very wide responsibilities to sub-national authorities and left a few key policies for national. Decentralization in Indonesia is altering indigenous values [2].

The persistent demand for the implementation of decentralization in Indonesia is relevant to the various experiences of other countries in the world. Centralization is said to have constrained the local government's role in providing quality public service especially in third world countries. The central government is not able to control the entire breadth and complexity of governance matters. Furthermore, governance will be very complicated for a nation which has a wide geographical area, numerous population, as well as ethnic, culture and language diversities like Indonesia as archipelago country which has thirteen thousand islands.

The basic legislation of decentralization on education sector was provided by the Law number 22 in 1999 which given wide authority to local governments. Though, the regulation on decentralization revised twice in 2004 and the latest regulation is enacted in 2014 however those are stick with the objective on decentralization to empower provinces and municipalities.

In Indonesia, rights of the national-local governments on education affairs are established in a written law, the sharing between them are also guaranteed by laws. It has been more than ten years Indonesia has changed the educational system from centralization to decentralization. Province and district play more important role in improving the quality of education in post decentralization compared to in centralization period. Some challenges have emerged, followed by questions regarding the extent to which a national can control its implementation.

However, transferring education sector under responsibility of local governments also has high risk. Decentralization may result negative impact when local governments cut their education budget to allocate on physical development [3]. The implementation of education decentralization is giving different faces within local governments in Indonesia. In terms of budget allocation: It is decrease in Bekasi City [4], butit is in increase in Solok City during 2005-2008 [5].

Basically decentralization policy enacted based on the belief that the quality of public administration at local level will be better if it is managed by them. Local affairs efficiency will be increased by the power shifting from national to local level [6]. Similar thought is used for education sector. It is commonly accepted that local education will improve if they can identify and solve problems faster, knows student-parent's need better, minimize national control and hence satisfy the local education stakeholders [7].

To illustrate the implementation of education sector post decentralization, the paper highlight some keys background, discuss on several aspects that closely related to the expectation of decentralization at local level. This paper will cover on how the local governments managed education sector under their responsibilities, it will consist; financial aspect, local innovation and education services quality. 


\section{RESEARCH METHOD}

The study is influenced by [8], which suggested that education decentralization covers five aspects. It consists of: local finance capacity, increasing level of effectiveness and efficiency, political redistribution, increasing education quality and increasing local innovation. However, this research construction model is based on Indonesia context. Research was conducted in four cities, Medan-North Sumatera, Bandung-West Java, Surabaya-East Java and Makassar-South Sulawesi. It is conducted by a blended qualitative and quantitative approach and collecting secondary data from various sources were used as a method of enquiry. Face-toface and phone interviews were conducted forinformants, survey by questionnaire with total 82 parents as respondents from all research areas.

\section{RESULT AND DISCUSSIONS}

Education is one of the authorities transferred from central to local governments that could be managed. In general, decentralization of education is a common phenomenon that also occurs in almost all parts of the world, particularly developing countries [8]. Basically, education decentralization is a transfer of authority and responsibility from central local educational institutions at local level. Decentralization in education sector implies transfer of power from national government officials to their counterparts at the provincial and municipalities, as is to increase efficiency in the management of education at local level [9], regarding planning and making decision based on local conditions [10]. The aim of decentralization in education sector in Indonesia is to develop local education which emphasize on diversity among local governments. It is interpreted as a delegation of power and authority to the local governments and local communities, which is bounded by National Education System [11]. Furthermore, [12] stated that decentralization education in Indonesia aimed to increase: (a) education quality (b)administration efficiency (c) cost-effectiveness (d) equityeducation for all. These should be basic of decentralization implementation and management in Indonesia.

\section{A. Local Education Spending}

The scope of decentralization on education sector in Indonesia is using two different concepts with similar goal. The first concept is transferring of authority from central to local government. In this concept, national government provides education standard along with the budget which needed to cover the responsibilities imposed. Generally, national government need to calculate each local education allocation but local governments will decide how much and what is necessary to be covered. The second concept relates of shifting decision making process on education sector from national to local level. The basic idea of this concept is that local people become important actor to know and decide the desired educational programs for themselves.

Direct impact of decentralization on education sector from national to local government is laid on financial management. It embraced a decidedly decentralizing approach to local governments, greatly increasing fiscal autonomy. If education at six years-primary level was under responsibility of local governments at pre-decentralization, it will be extended to nine-years education when decentralization law enacted. The local government's authority on education is increased significantly. However, since it was not imposed from above/national government, then its success will depend on how it shaped and it evolved over time from the bottom up process.

Budget allocation for education sector reaches $20,59 \%$ of IDR 408,5 trillion which is divided as a national spending (IDR 154,4 trillion) and IDR 254,1 trillion as local education spending. Based on collecting data among four local governments from year 2012-2016, it depicts a proportion of education sector spending to local budget. It can be seen that the range from $19 \%$ to $35 \%$. It seems that local governments have been working to follow national standard for providing education cost higher than $20 \%$ from their local budgets, except for Medan city, in year 2016 it decreased slightly. However if take a look deeply, this figure has several issues.

Firstly, education cost which is claimed as local governments spending do not sufficiently take into account as their capabilities. From around five hundred local governments in Indonesia, only Jakarta Province which did not receive national financial transfer under a general allocation fund program. However, four research areas are receivers and they are given as a state responsibility to provide public services for all citizens equally. General allocation fund aimed to fill disparity gap among local governments, the weakest get the most [13].

Figure 1:

Education Spending in Four Big Cities 2012-2016

\section{Education Spending}

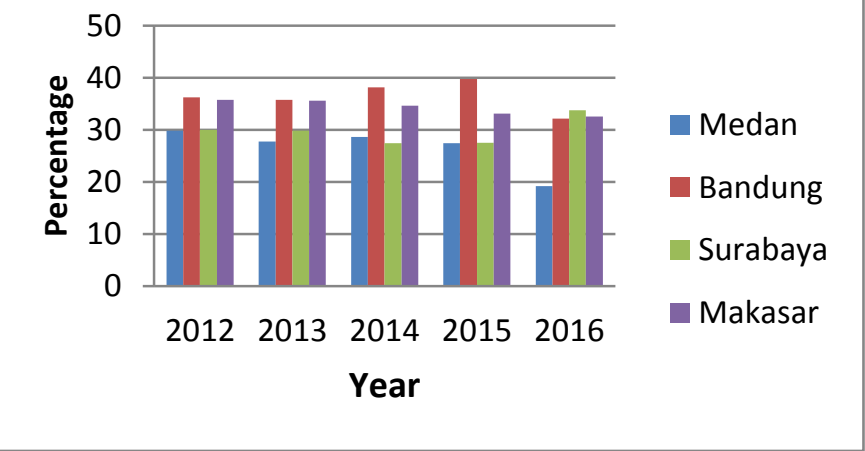

Source: By this research

Secondly, the education spending doesn't reflect education operational cost directly. It only goes to education activities at small portion $(2 \%-8 \%)$ but $92-98$ percent will be used for teacher and education staff salaries. In this case, local government function is only forwarding national money for remuneration post at education sector. In recent years, there are indications that most of the local government using national funds for personnel salaries. Holding high authority to control local affairs doesn't relate to strengthening financial capacity within local governments. The most severe problem of decentralization of government is lying in the field of local 
public finance indeed. Ideally, decentralization is the revenueraising power which is delegates to subordinate governments [14].

Local governments expenditure mostly funded by national allocation grant rather than their local revenue. Despite receive national-general allocation fund; local governments also receive school operational fund which distributed based on number of students on each area. Another national fund which released to local government is specific allocation fund which usually used for school building construction.

\section{B. Local Innovations}

One aspect that closely related to the successful of decentralized education is local innovations. The local innovations will determine the quality of education at each area. The changing of educational management from centralization to decentralization gave consequences that local governments have to give more attention on education affairs. The education management that was run by national should be also becomes a responsibility of them. By means of now education management has to conduct based on their local preferences.

The basic tasks that have to be managed was facilitating the local interest on education affairs. The initial stage was simply followed national-education standard which already set-up. Four research areas present a very similar picture on education management when it became under their jurisdiction. Respondents reveal similar comment on how they understand. From the beginning it was clearly what they have to do was followed the rules as it set-up by national. Local government is act as a national-branch. Most of the education standard is established by national laws. The national curriculum was available, -they just follow it, the teacher development program was initiated by Ministry of Education, and they just imitated the similar mechanism. The new-teacher remuneration system was established, though they were given as local government employee, the national will fully guaranteed transfer their salary to local government's account.

Most respondents testified that education management at local level implemented as it was. The basic foundation of education policy is dominated by national while some minor modifications did initiate in local context. Its education planning management was suitable on local-level preferences. They simply argue that national standard was systematicallyplanned and they provide strong institutional framework for local governments processing how it should be done. Though, the respondents agree that take a significant contribution on improving their education quality.

Two innovations exposed in this paper as local innovations; first is the utilizing ICT for student's enrollment; second is involving public participation. One of the new of innovation on education as it was claimed by all respondents is the use of IT on admission for enrollment system. Before, it was processed manually and it closed to popular control. It is regulated by national law and it justified at local level based on the average score achievements of local students against national exam results. This system is implementing nationwide. The locals managing its technical processes; set- up passing grade score, registration, selection and announce of the results. The whole process is done online and real-timebased. Nevertheless, on-line enrollment system is hardly to say as local initiative.

After decentralization at education sector implemented, school has authority to manage education activities, play vital role on decision-making process to improve the quality of education, human resources, including the professionalism of teachers and also how raising education fund from student [15]. One significant feature of education decentralization is public school tuition fee. Four research areas gave different implementation. If Surabaya and Makassar city enacted freetuition program for public school at all level show ever Medan and Bandung city is applying the opposite policy. The last two areas collect tuition for high school level. Education official staff in Medan and Bandung explained the student's participation needed at least for four reasons: encounter shortfall of national school operational aid, improve the quality standard of education for every single school, allow by law and involve local community on education. Why those areas behave so differently on tuition for high school when large responsibilities give in their hands?

Despite national block grant from which mostly used for government officers' salary (including teachers), national government also send school operational-aid for each students, called as BOS. It is a government program which is basically the provision of funding for non-personnel operational expenses for local governments as the implementer of compulsory education program. National regulation guides its utilization for thirteen items: purchasing textbook, library programs, extracurricular activities, student's test and exam, new student admission program, purchase consumables items, electricity, building maintenance, non-education staff allowance, teacher's development program, help low-income students, purchase computer hardware and managing of finance aid itself. If the policy of primary-free tuition for public and private school was started in 2005, it was just come in 2013 for high school. Firstly, the ultimate goal of BOS is to ensure compulsory education reaches all Indonesian children. But when it expands for high school level then it aimed to minimize education finance burden on student's parent. Basically, public high school is not supposed to collect tuition since it subsides by national level. Operational school operational-aid rose gradually from IDR 1 to 1.4 million per student per year from year 2013-2016. However, all education officers from research areas considered that it is not sufficient.

Luckily for Surabaya's students, in addition to the support national-education operational cost, their local government release subsides this aid through providing additional budget IDR 152.000/student/month. The cost is drawn from their own budget. It is strictly prohibited for any school principals to collect tuition for public school in Surabaya. Different mechanism applied in Makassar City when they pursue free tuition for any level of public schools. Makassar city is only channeling national aid directly to each school. There is no local subsidy for it. 
Different policy applied in Bandung City. Local government allows High school public school principal to collect tuition (called as education donation expenses) as long as it approved by each school committee as a representative of student's parents. The amount of money is formulated by school and school committee. Referred to Bandung City executive instruction it should not more than 300.000/student/month, but in fact many schools draw more.

Public school tuition in Bandung City is controversial. In one side, it is believed can increase education quality through parent's involving. Having additional funding, schools are expected to achieve the target. When we take a look at the process, it was conducted by democratic mechanism. Though it discussed and approved by school committee, however it's role also questionable. School committee was play more as a school's rubber stamp rather as a parents'/community's representative. In literature review stated that greater parental involvement through participation in school activities/program will directly impact on school quality [16]. However the powerfull of school on students makes their relation is imbalance. Many cases show that students were under pressure and not feel secure when tuition was not paid. The schools push them to hold 'poor card' from local authority [17].

\section{Education Quality}

The main purpose of decentralization of education sector in Indonesia is to improve student achievement while also pulling local authorities' attention to be more concern and participate to develop education based on their own sources [12]. Province and district play more important role in improving the quality of education in post decentralization comparing with in centralization period. The emphasizes of education decentralization policy has basically been on an effective way in increasing its quality. There is the idea that education decentralization is more success if it is given to local governments which provide them a mechanism responsive to the variety of local conditions and make decision more relevant to local needs. Local governments are given the responsibility for the broad-range aspect of education affairs. National law formally recognized that local governments would be responsible for these domains: planning and evaluation of school program, curriculum management, teaching-learning activities, financial management, teacher and education staff management, equipment and school facilities management. However, does decentralization improve education quality at local level? And if it changes, does positive or negative? Without touched at local level yet, when we take a look at the global measurement, it gave gloomy features.

UNESCO, in 2012 , reported that Indonesia is ranked $64^{\text {th }}$ out of 120 based on ratings Education Development Index (EDI). In 2011, Indonesia's EDI is on $69^{\text {th }}$ out of 127 countries. The total value was obtained from the summary EDI acquisition of four ratings categories: primary education enrollment rate, literacy rate at age 15 years and above, the rate of participation by gender, last number of students up to grade V at elementary School [18]. Also in 2012, according to
Global league table, Indonesian education quality is in lowest in the world, Indonesia are bottom along with Mexico and Brazil. Is it correlates with decentralization policy?

To know the change education quality, a short question asked to the parents as research respondents. The findings revealed different percentage, but around than three quarter ofrespondents; $75,3 \%$ in Medan, 76,1\% in Bandung, 74,7\% in Surabaya and $72,5 \%$ in Makassar thought that there is no significant change in education quality in their places. It is similar whether run by national or taken by local government.

This result is contrast with the ultimate goal of decentralization as national law expected. This also is not in line [8]. Indication many activities to improve quality of education has been carried out by local governments indeed, giving professional allowance as much as their monthly salary, conducting teacher's training/development program however the respondents viewed that is was set up by national and was not initiated by local governments. One that may contribute to this issue is the local-decentralizedprogram is similar with the previous which is implemented in centralization period. Therefore, the break through-policy from local government plays an important role in improving education quality.

One of pre-requisite for the sucessful of decentralization is that if local government have strong capacity and willingness, strong local institutions to design and implement it well [6]. Local governments has wide chance to improve education quality through their closeness to the local people. Local governments can increase their sensitivity to know local people need. Furthermore, they can give adverse result when local governments mislead carry out their functions. Even though the education management is given, the power and the role of Ministry of Education is still strong. The vital key of the successful of education decentralization is if finance and supply determined locally [9]. Here the argument will work well for country which has strong local government financial capacity so they can capure education affairs locally. However, it is not run optimally when the local dependency on financial is still high.

\section{CONCLUSIONS}

Education decentralization should be linked to management capacity of local governments. It is useless giving power but local governments not having sufficient capacity to implement those powers. Despite the fact that the authority is given widely under decentralization era, the local governments is taken narrowly. The financial problems faced by local governments are inevitable closely related with weak capacity that has to be made on education affairs. With low local government's revenue-small contribution on education, it is hard to improve quality of education at local level. Basically, the education decentralization in Indonesia is implemented not far from shifting education affairs management from national-local level, nothing changes significantly. In terms of public school tuition, this area presents a very different picture of how decentralization interpreted. Public school is free in some local governments but other local governments legalizing school principals to 
collect student contribution in other areas. The tuition is varying from one school to another within local governments. Public school claims that student contribution is complement to insufficient national-school operation aid. Student contribution for education in public school is a controversy when education affair is given to local government. Regarding local innovations hardly is vigorously pursued by local government, except controversial tuition fee policies for public school on behalf of involving local community participation on education. People's participation on education is constituted by law indeed. However, there is also the risk of capture on student's parents by public school management since it is run by minimal control.

\section{REFERENCES}

[1] Bardhan \& Mookherjee, 2006, Decentralization and Local Governance in Developing Countries, A comparative perspective, Massachusetts Institute of Technology

[2] Tyson Adam D, 2010, Decentralization and Adat revivalism in Indonesia : a Politics becoming indigenous, Routledge.

[3] Hane cannaway and Martin Carnoy 1983 Dentralization and School Improvement Can We Fulfill the Promise? San Fransisco Jossey-Bass Publishers.

[4] Hasbullah, 2010, Education autonomy and implications on education management, Jakarta, Rajawali Pres

[5] Mclure, Maureen \& Triaswati 2001 Bridging the generational divide strategy for school improvement within the context of fiscal dentralization.

[6] Litvack J, Ahmad J, Bird R, 1998, Rethinking Decentralization in Developing Countries, The World Bank, Washington DC.
[7] De Grauwe A, Balde L, Diakhate C, Dougnon M, Moustapha, Odushina, 2005, Does decentralization lead to school improvement? Findings and Lessons from research in West Africa, Journal of education for International Develpment 1(1), pp 1-15

[8] Leug Yin Hung Joan, 2004, The politics of Decentralization: A case study of school management reform in Hongkong, centralization and decentralization, Vol 13, CERC Studies in Comparative education,pp2138

[9] Winkler \& Gershberg, 2000, Education Decentralization in Latin America: The effect on the quality Schooling, in Annual World Bank Conference on Development in Latin America And the Caribbean Office, pp 203-220, World Bank

[10] Halim Abdul, 2010, capita selecta on local finance management, Bunga Rampai Manajemen Keungan Daerah, Yogyakarta, UPP AMP YPKN, 2010.

[11] Sufyarma, 2003, Capita Selecta on education management, Kapita selekta manajemen pendidikan, Alfabeta

[12] Arikunto, 2005, Analysis impact of education decentralization on municipalities education office, Dinamika Pendidikan no 01/Th.XII/Maret 2005, pp51-59

[13] Asanuma and Brodjonegoro, Indonesia decentralization Policy, origins, issues and prospects, http:www//icds.co.jp/sympo/pdf/S4(1),pdf.

[14] Smith BC, 1985, Decntrlization The territorial dimensions of the state, George Allen \& Unwin Ltd.

[15] Mulyasa, 2005, School-based manajement, Manajemen berbasis sekolah, Remaja Rosdakarya, Bandung

[16] Berhman J and King E, 2000, Competition and ender gap in wages, evidence from 16 countries, background paper for engendering development, World Bank, Washington DC

[17] Suhartanto Andang, 2014, the role and function of school commitee between reality and expectation http://awasibos.org/liputan/peran-danfungsi-komite-sekolah-antara-seharusnya-dan-kenyataan/

[18] Cladwell B, 2005, School based management, UNESCO's International institute for education planning. 